\title{
Discovery of Three Newly Described Single Nucleotide Polymorphisms in Mitochondrial DNA Hypervariable Region I (HVI) and Estimation of Variants and Haplotypes Encompassing Nucleotide Positions 16024- 16365
}

Imad $\mathrm{H}^{1 *}$, Abeer $\mathrm{F}^{2}$, Cheah $\mathrm{Y}^{1}$, Mohammed $\mathrm{J}^{2}$ and Aamera $\mathrm{O}^{3}$

${ }^{1}$ Department of Molecular Biology, Putra University, Kuala Lumpur City, Malaysia

${ }^{2}$ Department of Molecular Biology, Babylon University, Hilla City, Iraq

${ }^{3}$ Institute of medico-legal in Baghdad, Ministry of Health of Iraq, Iraq

\begin{abstract}
The aims of this research are to study the mitochondria noncoding region by using the Sanger sequencing technique and establish the degree of variation characteristic of a fragment. FTA ${ }^{\circledR}$ Technology (FTA ${ }^{T M}$ paper DNA extraction) utilized to extract DNA. A portion of a noncoding region encompassing positions 16024-16365 amplified in accordance with the Anderson reference sequence. PCR products purified by EZ-10 spin column then sequenced and detected by using the ABI 3730xL DNA Analyzer. The most frequent variant differed in the single position A16227G, according to the CRS sequence. A new polymorphic position 16046, 16105 and 16141 are described may in future be suitable sources for identification purpose. The data obtained can be used to identify variable nucleotide positions characterized by frequent occurrence most promising for identification variants.
\end{abstract}

Keywords: Encompassing nucleotide positions 16024-16365; HVI; Iraq; Mitochondrial DNA; Polymorphism

\section{Introduction}

The mitochondrial DNA (mtDNA) is a small circular genome located within the mitochondria in the cytoplasm of the cell. The mitochondrial genome can be divided into two sections: a large coding region, which is responsible for the production of various biological molecules involved in the process of energy production in the cell, and a smaller 1.2 kilobase pair fragment, called the control region. It is found to be highly polymorphic and harbors three hypervariable regions HVI, HVII and HVIII [1]. Mitochondrial DNA comprising of about 37 genes coding for 22 tRNAs, two rRNAs and 13 mRNAs are a small circle of DNA [2]. Mitochondrial DNA does not recombine and thus there is no change between parent and child, unlike nuclear DNA $[3,4]$. There is more sequence divergence in mitochondrial than in nuclear DNA $[5,6]$. This may be caused by a faster mutation rate in mtDNA that may result from a lack of repair mechanisms. Sequencing of highly polymorphic segments of the control region of mitochondrial DNA (mtDNA) is today a routine method of analysis of biological traces which are not suitable for STR analysis due to insufficient concentration of nuclear DNA or heavy degradation processes $[7,8]$. A promising approach in this context seems to be analysis of selected single nucleotide polymorphisms (SNPs) that are useful for identification purposes. The aim of this study was to sequence the portion of the noncoding region of mtDNA in order to ascertain the degree of variation present in this fragment and to find those particular polymorphic positions that fulfill the conditions necessary for their future application in the identification process.

\section{Materials and Methods}

\section{Population data}

Unrelated 324 healthy blood samples from the middle and south of Iraq provinces. The age of the donors was between 20 to 30 years old, due to the mtDNA will get more mutation after 30 years old in human (Figure1).

\section{Extraction of DNA}

Blood samples were taken by FTA (FTA ${ }^{\mathrm{TM}}$ paper DNA extraction) cards and sent it to the genetics laboratory.

\section{Amplification of mitochondrial DNA}

A portion of noncoding region encompassing positions from 16024 to 16365 amplified in accordance with the Anderson reference sequence [9] GenBank: J01415. This portion of DNA was amplified in two primers: the first one is HVI-F (16024-16045) 5'-TTCTTTCATGGGGAAGCAGATT-3' and the second HVI-R has a position (16365-16345) 5'-AGTCAAATCCCTTCTCGTCCC-3'. Add in $20 \mu \mathrm{L}$ of Master Mix into PCR tube. Change the pipette tip and add $20 \mu \mathrm{L}$ of Primer Mix into PCR tube. Add $10 \mu \mathrm{L}$ of extracting DNA into the PCR tube after changing the pipette tip again. Allow all the liquid settles at the bottom of the tube, and not elsewhere. Check the volume in the PCR tube using the PCR tube with $50 \mu \mathrm{L}$ in it. $95^{\circ} \mathrm{C}$ hold for 10 minutes, 30 cycles of: $94^{\circ} \mathrm{C}$ for 30 seconds, $52.5^{\circ} \mathrm{C}$ for 30 seconds, $65^{\circ} \mathrm{C}$ for 1 minute. $72^{\circ} \mathrm{C}$ hold for 10 minutes. $4^{\circ} \mathrm{C}$ hold, $\infty$ infinity is the cycling protocol for amplification of mtDNA PCR.

\section{Evaluation of mitochondrial DNA}

To confirm whether the mtDNA PCR product is amplified, we will

*Corresponding author: Imad $\mathrm{H}$, Department of Molecular Biology, Putra University, Kuala Lumpur City, Malaysia, Tel: 006-017-3642869; E-mail: imad_dna@yahoo.com

Received November 05, 2013; Accepted December 16, 2013; Published December 19, 2013

Citation: Imad H, Abeer F, Cheah Y, Mohammed J, Aamera O (2013) Discovery of Three Newly Described Single Nucleotide Polymorphisms in Mitochondrial DNA Hypervariable Region I $(\mathrm{HVI})$ and Estimation of Variants and Haplotypes Encompassing Nucleotide Positions 16024-16365. J Forensic Res 5: 209. doi:10.4172/2157-7145.1000209

Copyright: (C) 2013 Imad H, et al. This is an open-access article distributed unde the terms of the Creative Commons Attribution License, which permits unrestricted use, distribution, and reproduction in any medium, provided the original author and source are credited. 
Citation: Imad H, Abeer F, Cheah Y, Mohammed J, Aamera O (2013) Discovery of Three Newly Described Single Nucleotide Polymorphisms in Mitochondrial DNA Hypervariable Region I (HVI) and Estimation of Variants and Haplotypes Encompassing Nucleotide Positions 1602416365. J Forensic Res 5: 209. doi:10.4172/2157-7145.1000209

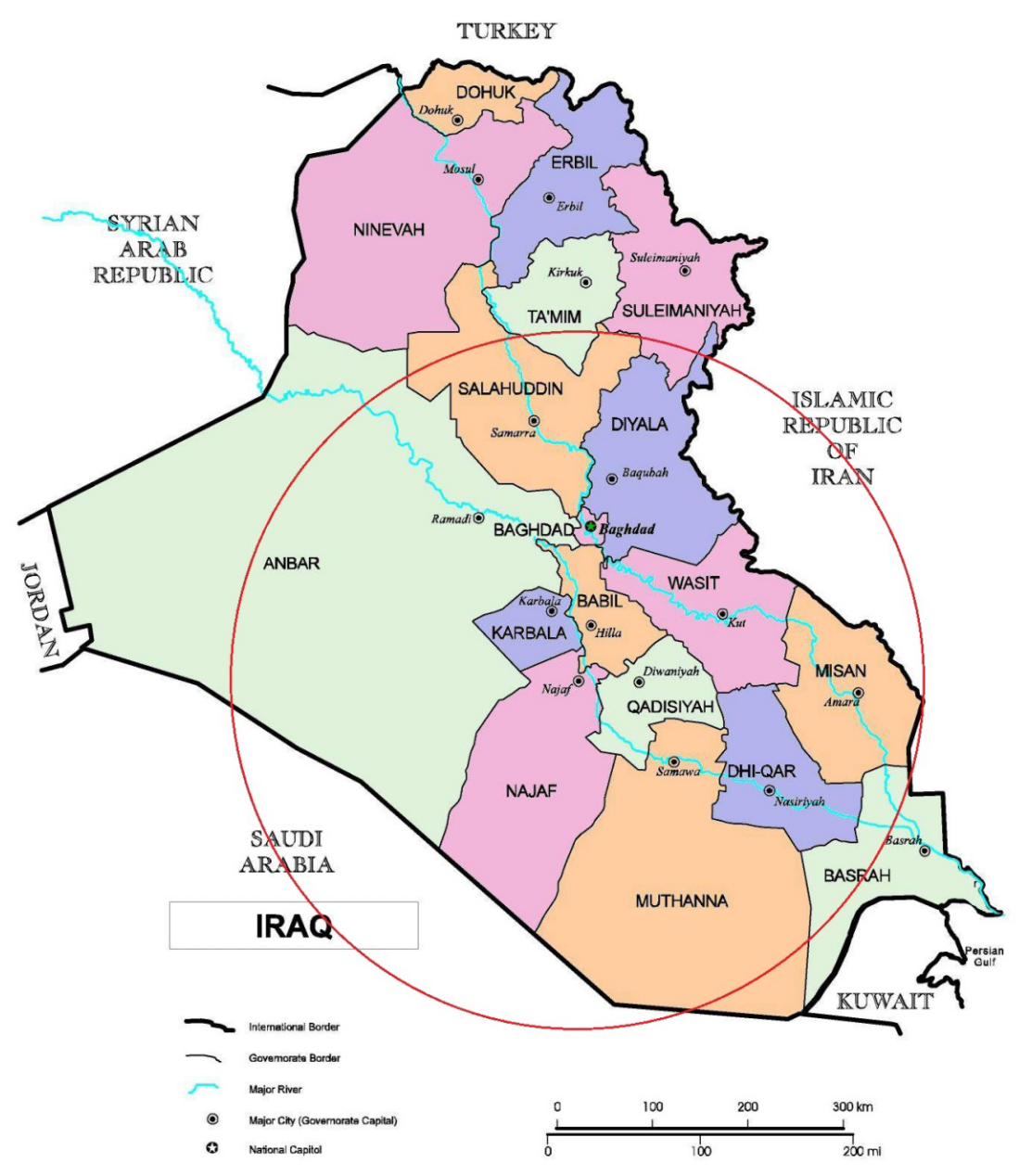

Figure 1: An Iraq administrative map showing the population and the central governorates where our samples came from (areas included in the red circle) (Source: UNOSAT, www.unosat.org, United Nations).

scrutinize the products of the amplification. Gel electrophoresis is used to do this. Here the electricity is used to force the movement of DNA fragments through a special gel. Since the DNA is negatively charged, it will move to the positive electrode in the electric field. The electric force causes the shorter portions of the DNA to move faster than the longer ones.

\section{Purification of mitochondrial DNA}

Using a special binding buffer, EZ-10 spin column purification kits using a silica gel membrane selectively absorb up to $10 \mu \mathrm{g}$ of DNA fragments. Since Nucleotides, oligos (<40-Meir), enzymes, mineral oil and other impurities do not EZ-10 Spin Column bind to the membrane, they are just removed. Here the DNA fragments can be separated in small amounts and can be used in further applications without any further treatment.

\section{Cycle sequencing and sequence analysis}

The DNA Sequencing of the PCR products was done using the BigDye TM Terminator. Utilizing POP-7 polymer (Applied Biosystems) polymer lot number 1206453 . The separation of the cycle sequencing products was carried out. Detection was by using the ABI $3730 \times$ L DNA Analyzer, cap array size 96, cap array length 50 . The reference sequence described by Anderson [9] was compared to the data observed.

\section{Cycle sequencing interpretation guidelines}

Within the noncoding region Mitochondrial DNA, sequencing results are studied from a consensus sequence derived from multiple sequence results. Data were analyzed by Sequencher ${ }^{\mathrm{TM}}$ (SEQUENCHER $^{\mathrm{TM}}$ 4.7 User Manual for Windows ${ }^{\odot}$ 1991-2007) [10] and aligned with the Anderson sequence using the sequence Navigator software. They are accepted by stating the nucleotide position followed by the code for the polymorphic base (for example, 263G).

\section{Statistical analysis}

Genetic diversity for the analyzed DNA fragment was calculated according to the formula: $\mathrm{D}=1-\sum p^{2}$.

Where $\mathrm{p}$ : frequencies of the observed haplotypes [11].

\section{Results}

The basic aim of this work was to assess the degree of variation characterizing a selected segment of the noncoding region of mtDNA. The study enabled identification of 103 different haplotypes and 28 
Citation: Imad H, Abeer F, Cheah Y, Mohammed J, Aamera O (2013) Discovery of Three Newly Described Single Nucleotide Polymorphisms in Mitochondrial DNA Hypervariable Region I (HVI) and Estimation of Variants and Haplotypes Encompassing Nucleotide Positions 1602416365. J Forensic Res 5: 209. doi:10.4172/2157-7145.1000209

Page 3 of 6

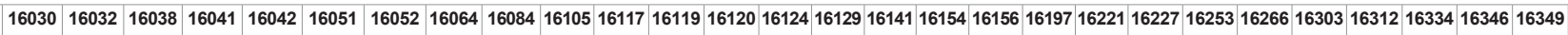

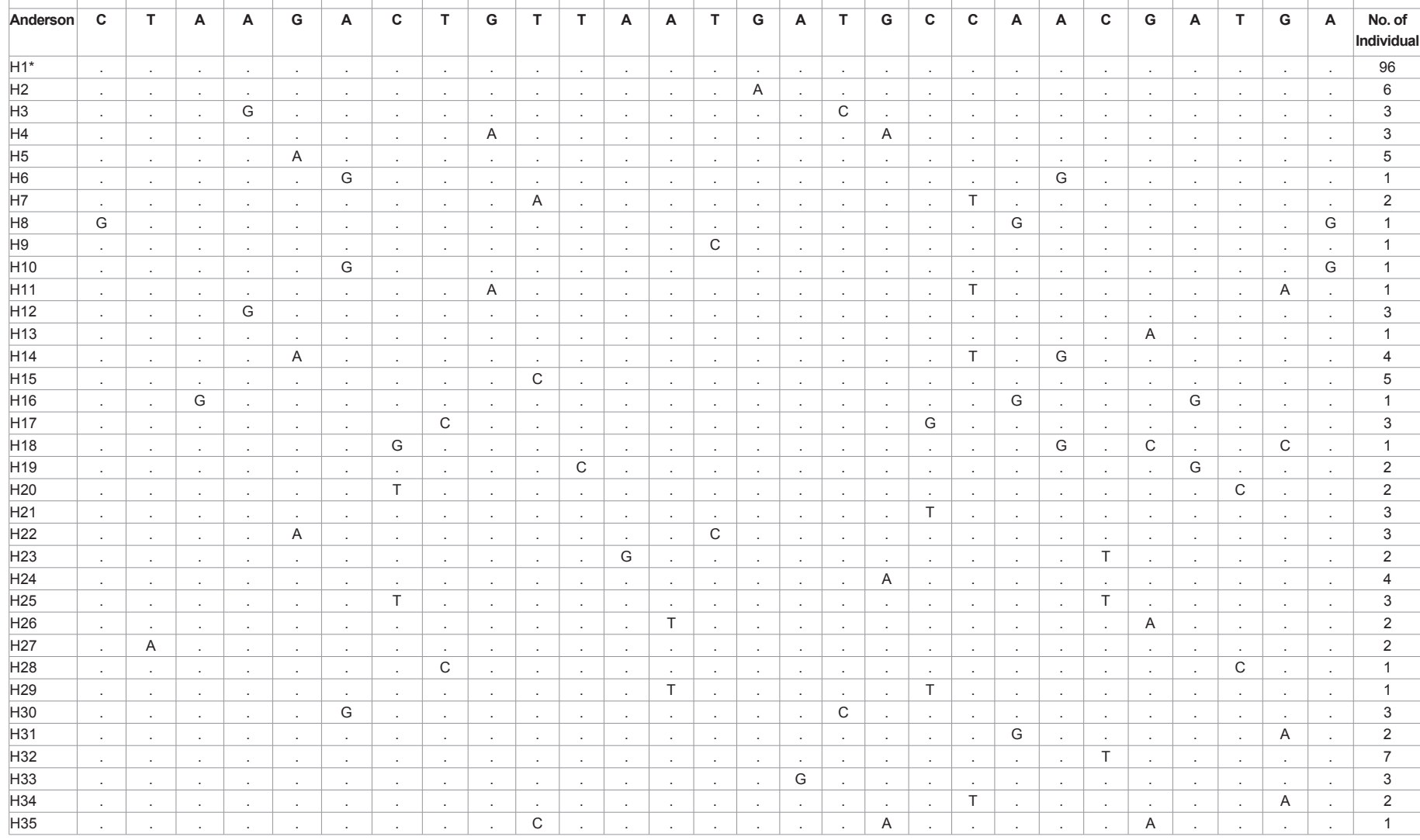

Table 1: Variable positions and Haplotypes.

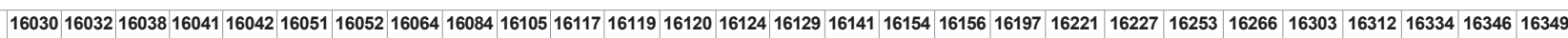

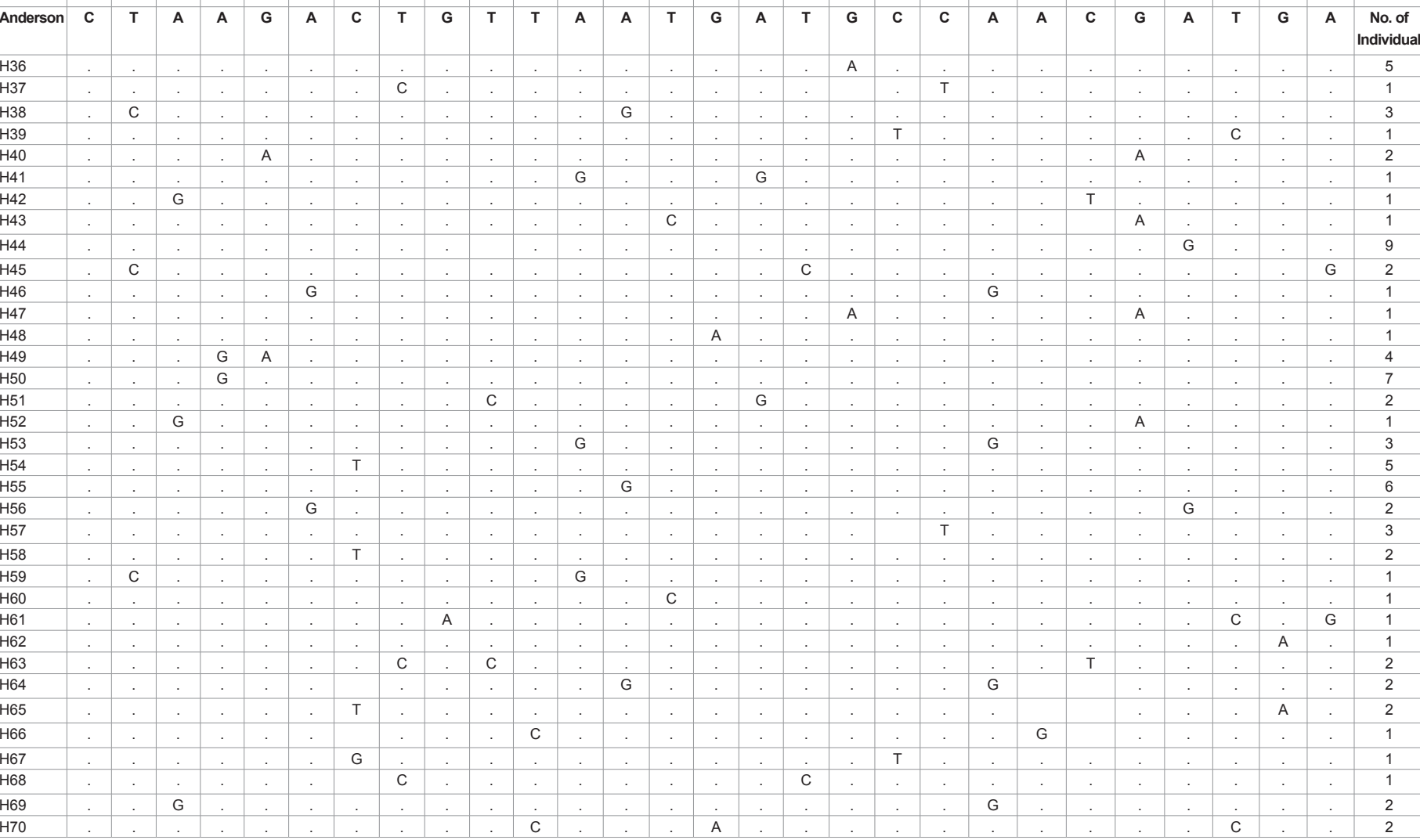

Table 1: Continued. 
Citation: Imad H, Abeer F, Cheah Y, Mohammed J, Aamera O (2013) Discovery of Three Newly Described Single Nucleotide Polymorphisms in Mitochondrial DNA Hypervariable Region I (HVI) and Estimation of Variants and Haplotypes Encompassing Nucleotide Positions 1602416365. J Forensic Res 5: 209. doi:10.4172/2157-7145.1000209

Page 4 of 6

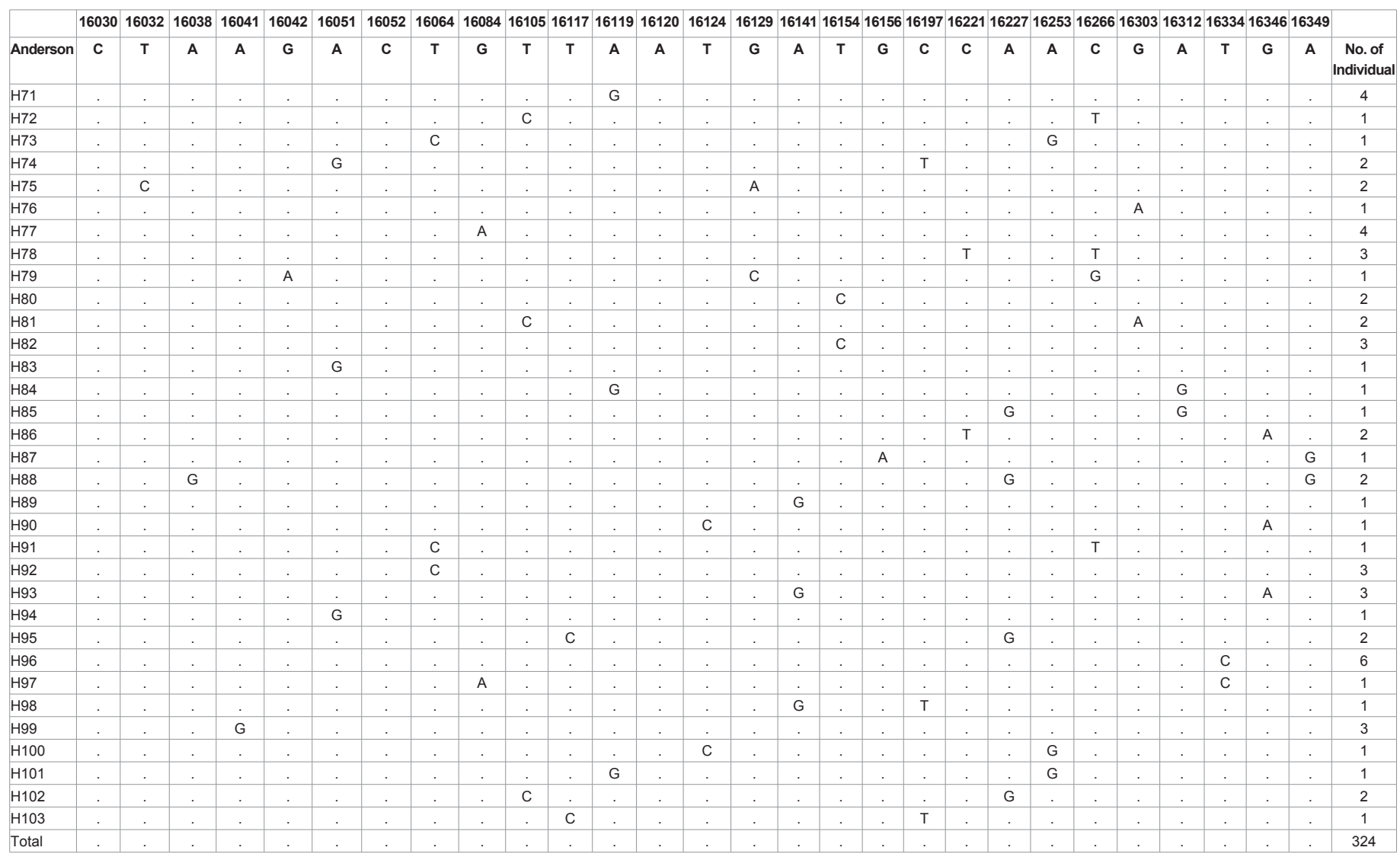

$H^{*}$ : Haplotype; G: Guanine; T: Thiamine; C: Cytosine; A: Adenine.

polymorphic nucleotide Positions Table 1. The most frequent variant (H1) was consistent with the Anderson sequence. Substitutions determined during the study are transitions and transversion. This fact is consistent with abundant literature data revealing significant domination of transitions over transversions [12,13]. Eleven polymorphic positions, 16030, 16032, 16025, 16105, 16120, 16129, 16197, 16266, 16303, 16346 and 16349 have transverse substitution Table 2. All the other substitutions determined during the analysis are transitions. The most frequent variant differed in the single position A16227G, according to the CRS sequence.

Comparative analysis of our results with previously published Iraqi data revealed significant differences in varying patterns $[14,15]$. This observation supports the thesis that different SNP-type polymorphisms can be strongly associated with a given population. Table 3 presents a summary of the Iraqi data in comparison with other global populations [16-18]. Significant assistance for the research was provided by Mitomap computer database, which contains information concerning human mtDNA [19]. This database includes data about currently known variable positions, their possible association with genetic diseases, and references to the literature. There is also a simple program called Mito Analyzer attached to the database which enables convenient access to information concerning polymorphic positions.

\section{Discussion}

The presence of more than one mitochondrial DNA (mtDNA) variant within a cell, tissue, or individual is emerging as an important component of eukaryotic genetic diversity. Yet the variations may vary from person to person. Therefore, to understand the polymorphisms at different sites, it is of critical importance to investigate the sequencing of mtDNA coding region's transmission. The first entire human mtDNA sequence was explained by Anderson et al. [9]. Cambridge Reference Sequence CRS is the name given to the published sequence used as a reference standard. For the coding function of the analyzed DNA fragment. Sequencing of the mitochondrial DNA coding region in the 300 unrelated donors showing a new polymorphic position 16046, 16105 and 16141 are described may in future be suitable sources for identification purpose. Sequence the portion of the noncoding region of mtDNA is in order to verify the degree of variation present in the fragment. It is also to identify those particular polymorphic positions that meets the conditions necessary for their future use in the identification process.

Earlier writings for a detailed description of molecular biology, genetics, sequence determination procedures, interpretation practices, and utility of mtDNA sequence analysis in forensic casework and human identification $[20,21]$. In cases where there is an abundance in the sample, for example mass graves in mass disasters, there are newly discovered forensically validated methods such as ESI-MS [22] Certainly, all such applications should have a strong grasp of the mtDNA variation that is present in the populations concerned. As an example, describing and frequency estimates of common mtDNA types and any population sub-structuring must be at hand [23]. Consequently, this may also increase the pool of samples with degraded and insufficient nuclear DNA for mitochondrial DNA analysis.

\section{Conclusion}

It will become easier to handle minute amounts of DNA or DNA 
Citation: Imad H, Abeer F, Cheah Y, Mohammed J, Aamera O (2013) Discovery of Three Newly Described Single Nucleotide Polymorphisms in Mitochondrial DNA Hypervariable Region I (HVI) and Estimation of Variants and Haplotypes Encompassing Nucleotide Positions 1602416365. J Forensic Res 5: 209. doi:10.4172/2157-7145.1000209

Page 5 of 6

\begin{tabular}{|c|c|c|c|c|c|}
\hline Positions & Mutation & $\begin{array}{l}\text { Type of } \\
\text { mutation }\end{array}$ & $\begin{array}{l}\text { Presence in } \\
\text { Mitomap }\end{array}$ & Frequency & Frequency $\%$ \\
\hline 16030 & Transversion & C-G & Presence & 0.003 & $0.3 \%$ \\
\hline 16032 & Transversion & T-A & Presence & \multirow{2}{*}{0.030} & \multirow{2}{*}{$3 \%$} \\
\hline 16032 & Transition & $T-C$ & Presence & & \\
\hline 16038 & Transition & A-G & Presence & 0.024 & $2.4 \%$ \\
\hline 16041 & Transition & A-G & Presence & 0.047 & $4.7 \%$ \\
\hline 16042 & Transition & G-A & Presence & 0.058 & $5.8 \%$ \\
\hline 16051 & Transition & A-G & Presence & 0.036 & $3.6 \%$ \\
\hline 16052 & Transversion & C-G & Presence & \multirow{2}{*}{0.043} & \multirow{2}{*}{$4.3 \%$} \\
\hline 16052 & Transition & C-T & Presence & & \\
\hline 16064 & Transition & $T-C$ & $\mathrm{New}^{*}$ & 0.030 & $3 \%$ \\
\hline 16084 & Transition & G-A & Presence & 0.061 & $6.1 \%$ \\
\hline 16105 & Transversion & T-A & New & \multirow{2}{*}{0.045} & \multirow{2}{*}{$4.5 \%$} \\
\hline 16105 & Transition & T-C & Presence & & \\
\hline 16117 & Transition & T-C & Presence & 0.024 & $2.4 \%$ \\
\hline 16119 & Transition & A-G & Presence & 0.037 & $3.7 \%$ \\
\hline 16120 & Transversion & A-T & Presence & 0.034 & $3.4 \%$ \\
\hline 16124 & Transition & T-C & Presence & 0.068 & $6.8 \%$ \\
\hline 16129 & Transition & G-A & Presence & \multirow{2}{*}{0.043} & \multirow{2}{*}{$4.3 \%$} \\
\hline 16129 & Transversion & G-C & Presence & & \\
\hline 16141 & Transition & A-G & New & 0.033 & $3.3 \%$ \\
\hline 16154 & Transition & $T-C$ & Presence & 0.042 & $4.2 \%$ \\
\hline 16156 & Transition & G-A & Presence & \multirow{2}{*}{0.047} & \multirow{2}{*}{$4.7 \%$} \\
\hline 16156 & Transition & G-T & Presence & & \\
\hline 16197 & Transversion & C-G & Presence & \multirow{2}{*}{0.045} & \multirow{2}{*}{$4.5 \%$} \\
\hline 16197 & Transition & C-T & Presence & & \\
\hline 16221 & Transition & C-T & Presence & 0.052 & $5.2 \%$ \\
\hline 16227 & Transition & $A-G$ & Presence & 0.047 & $4.7 \%$ \\
\hline 16253 & Transition & A-G & Presence & 0.058 & $5.8 \%$ \\
\hline 16266 & Transversion & C-G & Presence & \multirow{2}{*}{0.058} & \multirow{2}{*}{$5.8 \%$} \\
\hline 16266 & Transition & C-T & Presence & & \\
\hline 16303 & Transition & G-A & Presence & \multirow{2}{*}{0.036} & \multirow{2}{*}{$3.6 \%$} \\
\hline 16303 & Transversion & G-C & Presence & & \\
\hline 16312 & Transition & A-G & Presence & 0.023 & $2.3 \%$ \\
\hline 16334 & Transition & T-C & Presence & 0.046 & $4.6 \%$ \\
\hline 16346 & Transition & G-A & Presence & \multirow{2}{*}{0.045} & \multirow{2}{*}{$4.5 \%$} \\
\hline 16346 & Transversion & G-C & Presence & & \\
\hline 16349 & Transition & $A-G$ & Presence & \multirow{2}{*}{0.040} & \multirow{2}{*}{$4 \%$} \\
\hline 16349 & Transversion & A-T & Presence & & \\
\hline & & & $\begin{array}{l}\text { Genetic } \\
\text { diversity* }\end{array}$ & $\begin{array}{l}\mathrm{D}=1- \\
\Sigma p^{2}=0.963=96.3 \%\end{array}$ & \\
\hline
\end{tabular}

$\mathrm{New}^{*}$ : new polymorphic positions; Genetic diversity* Genetic diversity for the analysed DNA fragment was calculated according to the formula: $\mathrm{D}=1-\sum p^{2}$

Table 2: Types of mutations and Frequency in a variable positions.

that is badly degraded with the coming of more techniques. Individual nucleotides may differ, and on top of that their number may differ. A new polymorphic positions are described may in future be suitable sources for identification purpose.

\section{Acknowledgements}

I sincerely wish to thank Prof. Issam for providing me the opportunity to work on this project. I am indebted to you for choosing the project, your enthusiasm for helping me and your patience and guidance as I progress to put this project together. I am thankful to you for helping me through the various analysis stages, and for providing helpful criticism and feedback throughout the writing process. also would like to thank Dr. Khalifa from the Institution of medico-legal for all time put in to discuss the project and helping me to put the project together. I would also like to thank Zainab Al-Habubi from the Department Biology for her guidance and help in the laboratory work.

\section{References}

1. Kraytsberg Y, Schwartz M, Brown TA, Ebralidse K, Kunz WS, et al. (2004) Recombination of human mitochondrial DNA. Science 304: 981

2. Helgason A, Hrafnkelsson B, Gulcher JR, Ward R, Stefánsson K (2003) A

\begin{tabular}{|c|c|c|c|c|c|c|}
\hline Population & Iraq $^{1}$ & India ${ }^{2}$ & Malaysia $^{3}$ & Africa ${ }^{4}$ & German $^{5}$ & \begin{tabular}{|l} 
US \\
Caucasian
\end{tabular} \\
\hline Sample size & 320 & 98 & 195 & 111 & 200 & 604 \\
\hline No. of variant sites & 28 & 83 & 149 & 97 & 153 & 233 \\
\hline$A \rightarrow G$ & 64 & 233 & 473 & 323 & 330 & 1112 \\
\hline $\mathrm{G} \rightarrow \mathrm{A}$ & 34 & 66 & 81 & 78 & 55 & 219 \\
\hline $\mathrm{T} \rightarrow \mathrm{C}$ & 40 & 145 & 461 & 382 & 308 & 1007 \\
\hline $\mathrm{C} \rightarrow \mathrm{T}$ & 28 & 117 & 321 & 486 & 199 & 688 \\
\hline$\%$ Transition & 93.26 & 94.85 & 92.16 & 95.77 & 95.61 & 97.61 \\
\hline$A \rightarrow T$ & 2 & 1 & 2 & 0 & 4 & 2 \\
\hline$A \rightarrow C$ & 0 & 23 & 81 & 15 & 5 & 47 \\
\hline $\mathrm{G} \rightarrow \mathrm{T}$ & 0 & 0 & 0 & 18 & 0 & 1 \\
\hline $\mathrm{G} \rightarrow \mathrm{C}$ & 6 & 0 & 3 & 0 & 1 & 6 \\
\hline$C \rightarrow A$ & 0 & 0 & 30 & 17 & 11 & 12 \\
\hline$C \rightarrow G$ & 2 & 4 & 1 & 6 & 19 & 6 \\
\hline $\mathrm{T} \rightarrow \mathrm{A}$ & 2 & 7 & 5 & 0 & 1 & 0 \\
\hline $\mathrm{T} \rightarrow \mathrm{G}$ & 0 & 0 & 3 & 0 & 0 & 0 \\
\hline$\%$ Transversion & 6.74 & 5.15 & 7.84 & 4.23 & 4.39 & 2.39 \\
\hline Insertion & 0 & 168 & 322 & 140 & 291 & 983 \\
\hline Deletion & 0 & 0 & 28 & 6 & 6 & 14 \\
\hline
\end{tabular}

Note: \% of transitions and transversions were calculated as number of observations divided by total substitution times 100 .

${ }^{1}$ This study.

${ }^{2}$ Reference: [16],

${ }^{3}$ Reference: [17],

${ }^{4}$ Reference: [17],

Reference: [18]

${ }^{6}$ Reference: [17]

Table 3: Comparisons of the characteristics across HV1 of the D-loop region in different human population groups.

populationwide coalescent analysis of Icelandic matrilineal and patrilineal genealogies: evidence for a faster evolutionary rate of mtDNA lineages than $Y$ chromosomes. Am J Hum Genet 72: 1370-1388.

3. Ingman M, Gyllensten U (2003) Mitochondrial genome variation and evolutionary history of Australian and New Guinean aborigines. Genome Res 13: $1600-1606$.

4. Chung U, Lee HY, Yoo JE, Park MJ, Shin KJ (2005) Mitochondrial DNA CA dinucleotide repeats in Koreans: the presence of length heteroplasmy. Int $\mathrm{J}$ Legal Med 119: 50-53.

5. Brown JR, Beckenbach AT, Smith MJ (1993) Intraspecific DNA sequence variation of the mitochondrial control region of white sturgeon (Acipenser transmontanus). Mol Biol Evol 10: 326-341.

6. De Benedetto G, Nasidze IS, Stenico M, Nigro L, Krings M, et al. (2000) Mitochondrial DNA sequences in prehistoric human remains from the Alps. Eur J Hum Genet 8: 669-677.

7. Holland MM, Parsons TJ (1999) Mitochondrial DNA sequence analysis validation and use for forensic casework. Forensic Sci Revi 11: 21-48.

8. Tzen CY, Wu TY, Liu HF (2001) Sequence polymorphism in the coding region of mitochondrial genome encompassing position 8389-8865. Forensic Sci Int 120: 204-209.

9. Anderson S, Bankier AT, Barrell BG, de Bruijn MH, Coulson AR, et al. (1981) Sequence and organization of the human mitochondrial genome. Nature 290 457-465.

10. SEQUENCHER ${ }^{\mathrm{TM}}$ 4.7 User Manual for Windows ${ }^{\odot}$ 1991-2007 Gene Codes Corporation, Inc. All rights reserved.

11. Jones DA (1972) Blood samples: probability of discrimination. J Forensic Sci Soc 12: 355-359.

12. Brown WM, Prager EM, Wang A, Wilson AC (1982) Mitochondrial DNA sequences of primates: tempo and mode of evolution. J Mol Evol 18: 225-239.

13. Yang Z, Yoder AD (1999) Estimation of the transition/transversion rate bias and species sampling. J Mol Evol 48: 274-283.

14. Al-Zahery N, Semino O, Benuzzi G, Magri C, Passarino G, et al. (2003) Y-chromosome and mtDNA polymorphisms in Iraq, a crossroad of the early human dispersal and of post-Neolithic migrations. Mol Phylogenet Evol 28: 458-472. 
Citation: Imad H, Abeer F, Cheah Y, Mohammed J, Aamera O (2013) Discovery of Three Newly Described Single Nucleotide Polymorphisms in Mitochondrial DNA Hypervariable Region I (HVI) and Estimation of Variants and Haplotypes Encompassing Nucleotide Positions 1602416365. J Forensic Res 5: 209. doi:10.4172/2157-7145.1000209

Page 6 of 6

15. Al-Zahery N, Pala M, Battaglia V, Grugni V, Hamod MA (2011) In search of the genetic footprints of Sumerians: a survey of $Y$-chromosome and mtDNA variation in the Marsh Arabs of Iraq. BMC Evolutionary Biology 11: 288

16. Mountain JL, Hebert JM, Bhattacharyya S, Underhill PA, Ottolenghi C, et al. (1995) Demographic history of India and mtDNA-sequence diversity. Am J Hum Genet 56: 979-992.

17. Budowle B, Wilson MR, DiZinno JA, Stauffer C, Fasano MA, et al. (1999) Mitochondrial DNA regions HVI and HVII population data. Forensic Sci Int 103: 23-35.

18. Lutz S, Weisser HJ, Heizmann J, Pollak S (1998) Location and frequency of polymorphic positions in the mtDNA control region of individuals from Germany. Int J Legal Med 111: 67-77.

19. Mitomap: A Human Mitochondrial Genome Database.
20. Holland MM, McQuillan MR, O'Hanlon KA (2011) Second generation sequencing allows for mtDNA mixture deconvolution and high resolution detection of heteroplasmy. Croat Med J 52: 299-313.

21. Homer N, Szelinger S, Redman M, Duggan D, Tembe W, et al. (2008) Resolving individuals contributing trace amounts of DNA to highly complex mixtures using high-density SNP genotyping microarrays. PLoS Genet 4: e1000167.

22. Warshauer DH, King J, Eisenberg AJ, Budowle B (2013) Validation of the PLEX-ID ${ }^{\mathrm{TM}}$ mass spectrometry mitochondrial DNA assay. Int J Legal Med 127: 277-286.

23. Sosa MX, Sivakumar IK, Maragh S, Veeramachaneni V, Hariharan R, et al. (2012) Next-generation sequencing of human mitochondrial reference genomes uncovers high heteroplasmy frequency. PLoS Comput Biol 8: e1002737. 